\title{
KORELASI KADAR PROLAKTIN DAN OKSITOSIN DENGAN LAMA AMENORE LAKTASI PADA IBU MENYUSUI EKSKLUSIF
}

\author{
Junaida Rahmi $^{*}$, Eryati Darwin ${ }^{2}$, Arni Amir $^{3}$ \\ ${ }^{1}$ Program Studi Magister S2 Kebidanan FK UNAND, Jalan Perintis Kemerdekaan No.94, Padang 25127, Indonesia \\ ${ }^{2}$ Bagian Anatomi Patologi FK UNAND, Jalan Perintis Kemerdekaan No.94, Padang 25127, Indonesia \\ ${ }^{3}$ Bagian Biologi FK UNAND, Jalan Perintis Kemerdekaan No.94, Padang 25127, Indonesia
}

Informasi Artikel:

Diterima: Juli,2017

Disetujui: September 2017

* Korespondensi penulis. rahmijunaida@gmail.com

\begin{abstract}
ABSTRAK
Prolaktin dan oksitosin merupakan hormon yang berperan penting dalam proses laktasi. Penelitian ini bertujuan untuk mengetahui korelasi kadar prolaktin dan oksitosin dengan lama amenore laktasi pada ibu menyusui eksklusif. Penelitian ini mneggunakan desain cross sectional, observasional terhadap 48 ibu menyusui eksklusif di wilayah kerja Puskesmas Belimbing Padang, September 2015 - Juni 2016. Sampel dipilih berdasarkan cluster random sampling. Pemeriksaan kadar prolaktin dan oksitosin dilakukan dilaboratorium Biomedik menggunakan Human Prolactin ELISA Kit dan Human Oxytocin ELISA Kit. Korelasi kadar prolaktin dan oksitosin dengan lama amenore laktasi diuji dengan menggunakan uji korelasi Spearman. Hasil penelitian menunjukkan terdapat korelasi positif yang lemah dan signifikan antara kadar prolaktin dengan lama amenore laktasi $(\mathrm{r}=0,331 ; \mathrm{p}=0,022)$, dan terdapat korelasi negatif yang sangat lemah dan tidak signifikan antara kadar oksitosin dengan lama amenore laktasi $(\mathrm{r}=-0,085 ; \mathrm{p}=0,565)$. Kesimpulan, semakin tinggi kadar prolaktin maka semakin bertambah lama amenore laktasi dan semakin tinggi kadar oksitosin maka semakin berkurang lama amenore laktasi.
\end{abstract}

Kata kunci: Prolaktin, Oksitosin, Lama Amenore Laktasi, Menyusui Eksklusif

\begin{abstract}
Prolactin and oxytocin were hormones that play important roles in breastfeeding. This study aim of this research is to determine the correlation between prolactin and oxytocin level with duration of amenorrhea lactation in exclusively breastfeeding mothers. We used crosssectiona design, by observing 48 exclusively breastfeeding mothers in Public Health Centre Padang Belimbing, September 2015 - June 2016. Samples were selected with cluster random sampling. Examination of prolactin and oxytocin level was conducted at Biomedical Lab with ELISA method. Spearman's correlation was used for analyzing prolactin and oxytocin level with duration of amenorrhea lactation. The result shows that there is a weak positive correlation and significance between prolactin and period of amenorrhea lactation $(r=0.331$; $p=0.022$ ), there is a very weak negative correlation and no significant between oxytocin levels with the length of amenorrhea lactation $(r=-0.085 ; p=0.565)$. It is concluded that the higher prolactin level, the longer amenorrhea lactation period is and the higher oxytocin level, the shorter amenorrhea lactation period is.
\end{abstract}

Keywords : Prolactin, Oxytocin, Duration of Amenorrhea Lactation, Exclusive Breastfeeding

\section{PENDAHULUAN}

Menyusui dan kehamilan merupakan hal yang sangat penting dalam kesehatan reproduksi wanita. Kembalinya menstruasi dan ovulasi bervariasi setiap ibu postpartum, hal ini ditentukan apakah ibu menyusui eksklusif atau tidak menyusui eksklusif. Pada ibu menyusui eksklusif memiliki kecenderungan yang lebih lama untuk mengalami periode anovulasi dan amenore, sedangkan ibu yang tidak menyusui eksklusif menstruasi biasanya terjadi pada 6 minggu postpartum. Hal ini menyebabkan interval kelahiran rata-rata menjadi lebih lama pada ibu menyusui eksklusif (Blackburn, 2013).

Berdasarkan Survei Demografi Kesehatan Indonesia (SDKI) tahun 2012, Proporsi wanita amenore turun dari $29,1 \%$ pada 6-7 bulan postpartum menjadi $21,4 \%$ pada $8-9$ bulan postpartum. Median kembalinya menstruasi setelah persalinan di Indonesia adalah 3,1 bulan 
pada tahun 2007 dan mengalami penurunan menjadi 2,4 bulan pada tahun 2012. Pemberian Air Susu Ibu (ASI) setelah melahirkan dapat melindungi wanita dari kehamilan melalui periode lamanya amenore (SDKI, 2007; SDKI, 2012).

Air susu ibu merupakan makanan terbaik untuk bayi pada awal kehidupan. World Health Organization (WHO) tahun 2012, merekomendasikan sebaiknya bayi diberikan ASI selama paling sedikit 6 bulan dan makanan padat seharusnya diberikan sesudah bayi berumur 6 bulan dan pemberian ASI dilanjutkan sampai anak berumur dua tahun. Cakupan ASI eksklusif di Negara Amerika tahun 2012 yaitu hanya 32,1\% pada 6 bulan pertama kelahiran (Heymann \& Earle, 2013; WHO \& UNICEF, 2012).

Pemberian ASI mempunyai dampak positif baik bagi ibu maupun bagi bayi, bagi bayi menyusui mempunyai peran penting untuk pertumbuhan, perkembangan, kesehatan dan kelangsungan hidup bayi, karena ASI kaya dengan zat gizi makronutrien dan mikronutrien. Bagi ibu, menyusui dapat mengurangi resiko perdarahan postpartum, involusi uteri lebih cepat karena peningkatan kadar oksitosin, menjarangkan kehamilan yang disebabkan karena terjadinya amenore laktasi, mengurangi risiko kanker payudara dan kanker ovarium, lebih ekonomis dan praktis (WHO, 2002; American Academy of Pediatrics, 2005; Ballard \& Morrow, 2013).

Cakupan ASI eksklusif di Indonesia pada tahun 2010 adalah 33,6\%, meningkat menjadi 38,5\% pada tahun 2011 dan $42 \%$ pada tahun 2012 serta mengalami penurunan pada tahun 2013 menjadi $30,2 \%$. Rendahnya cakupan ASI eksklusif secara Nasional tentu perlu mendapat perhatian lebih dari pemerintah. Penggalakan ASI memang bukan hal yang baru namun berbagai upaya untuk meningkatkannya terus dilakukan baik oleh pemerintah maupun swasta dan juga masyarakat peduli ASI, karena hasil cakupan ASI eksklusif belum mencapai target yang diinginkan secara Nasional yaitu sebanyak $80 \%$. Hal ini terjadi karena rendahnya pencapaian program ASI eksklusif pada setiap Provinsi dan wilayah Kabupaten dan Kota di Indonesia (SDKI, 2012;
Kementerian Kesehatan Republik Indonesia, 2013; Riset Kesehatan Dasar, 2013).

Cakupan pemberian ASI eksklusif di Provinsi Sumatera Barat (Sumbar) yaitu di Kota Padang pada tahun 2014 mencapai 72,2\%. Pencapaian ini masih jauh di bawah target nasional sebesar $80 \%$ di tahun 2015. Dari 22 Puskesmas di Kota Padang, Puskesmas dengan cakupan ASI eksklusif paling tinggi adalah puskesmas Alai 90,6\% dan cakupan ASI eksklusif paling tinggi kedua adalah Puskesmas Belimbing 85,6\%. Cakupan ASI eksklusif paling rendah berada pada wilayah kerja Puskesmas Air Dingin 52,6\% (Dinas Kesehatan Kota (DKK) Padang, 2014).

Pemberian ASI awal sampai bayi berumur 6 bulan dapat dipengaruhi beberapa faktor yaitu proses pertumbuhan jaringan pembuat ASI, penurunan produksi dan pengeluaran ASI setelah melahirkan yang disebabkan oleh kurangnya rangsangan hormon prolaktin dan oksitosin (Guyton \& Hall, 2006; Jamilah, dkk, 2013).

Prolaktin dan oksitosin adalah hormon yang berperan penting dalam proses laktasi. Prolaktin merupakan hormon utama dalam produksi ASI. Selain itu, prolaktin juga berpengaruh terhadap ovarium. Saat bayi menyusui maka oksitosin juga dilepaskan sebagai respon stimulasi puting susu. Oksitosin berpengaruh pada pengeluaran ASI "milk ejection". Selain itu, oksitosin juga berpengaruh terhadap ovarium dan korpus luteum (Lawrence \& Lawrence, 2014; Gimpl \& Fahrenholz, 2010).

Ketika bayi menyusui maka akan merangsang hipotalamus, selanjutnya akan merangsang adenohipofise (hipofisis anterior) sehingga mengeluarkan prolaktin. Hormon ini merangsang sel-sel alveoli yang berfungsi untuk membuat air susu. Bersamaan dengan pembentukan prolaktin oleh hipofisis anterior, rangsangan yang berasal dari isapan bayi ada yang dilanjutkan ke neurohipofisis (hipofisis posterior) sehingga mengeluarkan oksitosin. Selanjutnya oksitosin diangkut oleh darah ke payudara untuk menimbulkan kontraksi sel-sel mioepitel. Kontraksi dari sel-sel mioepitel akan memeras air 
susu yang telah dibuat oleh alveoli dan masuk ke sistem duktulus, selanjutnya mengalir melalui duktus laktiferus masuk ke mulut bayi (Guyton \& Hall, 2006).

Ketika ibu memberikan ASI secara kontiniyu maka dapat menekan terjadinya ovulasi sebab prolaktin yang sampai di hipotalamus akan menimbulkan hambatan sekresi Gonadotopin Releasing Hormone (GnRH) sehingga kadar Follicle Stimulating Hormone (FSH) dan Luteinizing Hormone (LH) menurun. Hal ini mengakibatkan gangguan siklus menstruasi yang menyebabkan tidak terjadinya menstruasi atau sering disebut sebagai amenore laktasi (Horseman \& Gregerson, 2015). Selain pemberian ASI eksklusif, beberapa faktor lain yang memengaruhi siklus menstruasi adalah stress, kecemasan, merokok dan alkohol. Hal ini berhubungan dengan respon dari aksis Hipotalamus Hipofisis Adrenal (HPA) (Liu et al., 2004; Lonstein, 2007; Lennartsson and Jonsdottir, 2011).

Sebagian besar penelitian membuktikan bahwa menyusui eksklusif atau laktasi yang ketat dipertahankan dapat menunda dimulainya kembali siklus ovarium dan menstruasi. Sekitar 29,5\% wanita menyusui eksklusif memiliki menstruasi pertama sebelum enam bulan postpartum. Sesudah 6 bulan ibu sudah memperkenalkan makanan tambahan pada bayi maka ibu juga berisiko untuk menstruasi sehingga ada kemungkinan peningkatan kehamilan. Hal ini disebabkan karena terjadinya perubahan hormonal terutama prolaktin dan oksitosin (García \& Mella, 2013).

\section{BAHAN DAN METODE}

Desain penelitian adalah cross sectional, observasional terhadap 48 ibu menyusui eksklusif di wilayah kerja Puskesmas Belimbing Padang, September 2015 - Juni 2016. Sampel dipilih berdasarkan cluster random sampling. Pemeriksaan kadar prolaktin dan oksitosin dilakukan dilaboratorium Biomedik Fakultas Kedokteran Unand dengan Human Prolactin ELISA Kit dan Human Oxytocin ELISA Kit. Uji normalitas data dengan Shapiro-Wilk, uji korelasi kadar prolaktin dan oksitosin dengan lama amenore laktasi dengan menggunakan uji korelasi Spearman.

\section{HASIL DAN PEMBAHASAN}

Tabel 1. Distribusi Kadar Prolaktin, Kadar Oksitosin dan Lama Amenore Laktasi pada Ibu Menyusui Eksklusif

\begin{tabular}{|c|c|c|}
\hline Variabel & Median & Minimum-Maksimum \\
\hline $\begin{array}{l}\text { Kadar Prolaktin } \\
\text { serum }(\mu \mathrm{UI} / \mathrm{ml})\end{array}$ & 932,458 & $169,760-4021,346$ \\
\hline $\begin{array}{l}\text { Kadar Oksitosin } \\
\text { serum }(\mathrm{pg} / \mathrm{ml})\end{array}$ & 45,693 & $1,520-954,883$ \\
\hline $\begin{array}{l}\text { Lama Amenore } \\
\text { Laktasi (hari) }\end{array}$ & 151,000 & $50,000-266,000$ \\
\hline
\end{tabular}

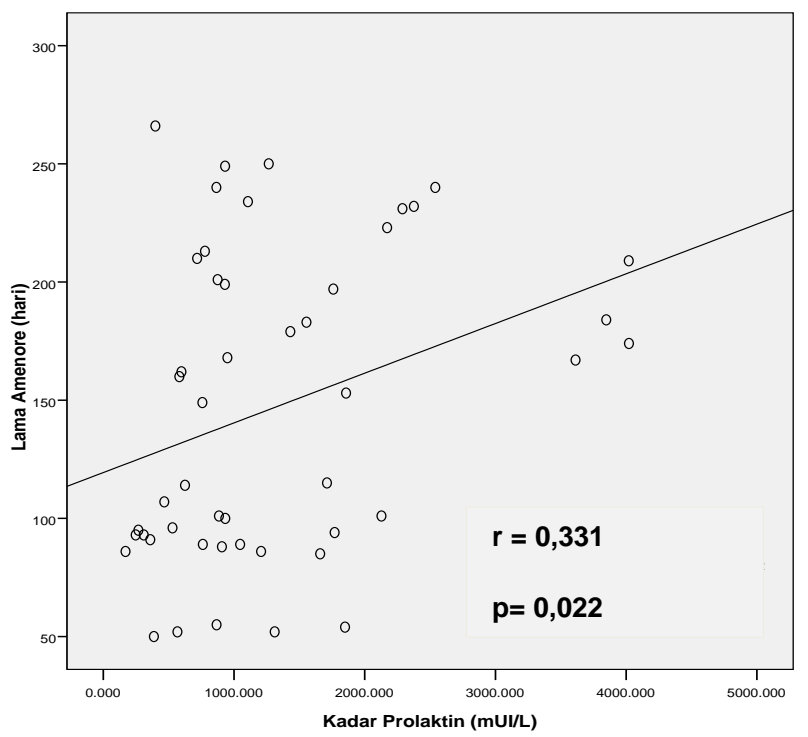

Gambar 1. Scatter Plot Korelasi Kadar Prolaktin dengan Lama Amenore Laktasi pada Ibu Menyusui Eksklusif 


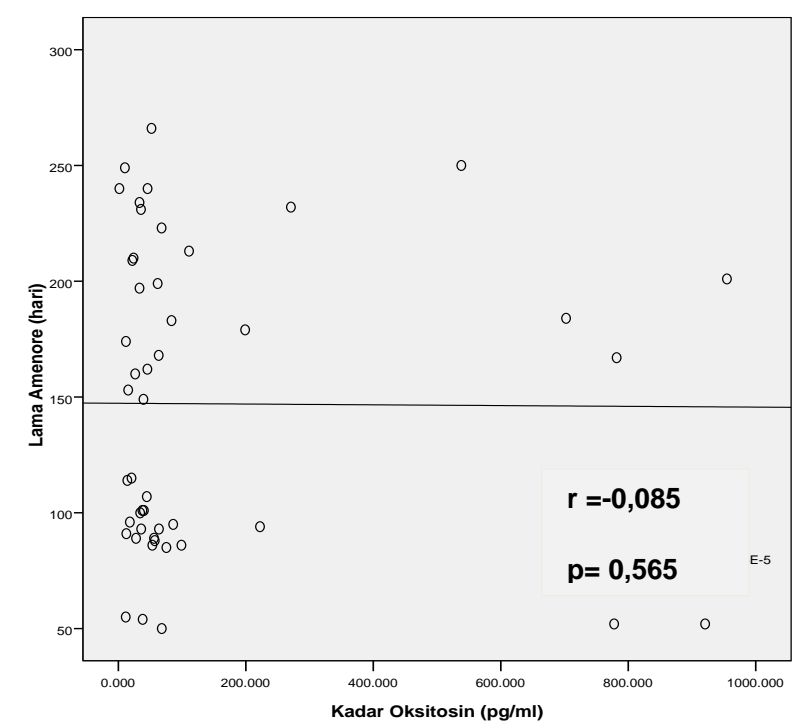

Gambar 2. Scatter Plot Korelasi Kadar Oksitosin dengan Lama Amenore Laktasi pada Ibu Menyusui Eksklusif

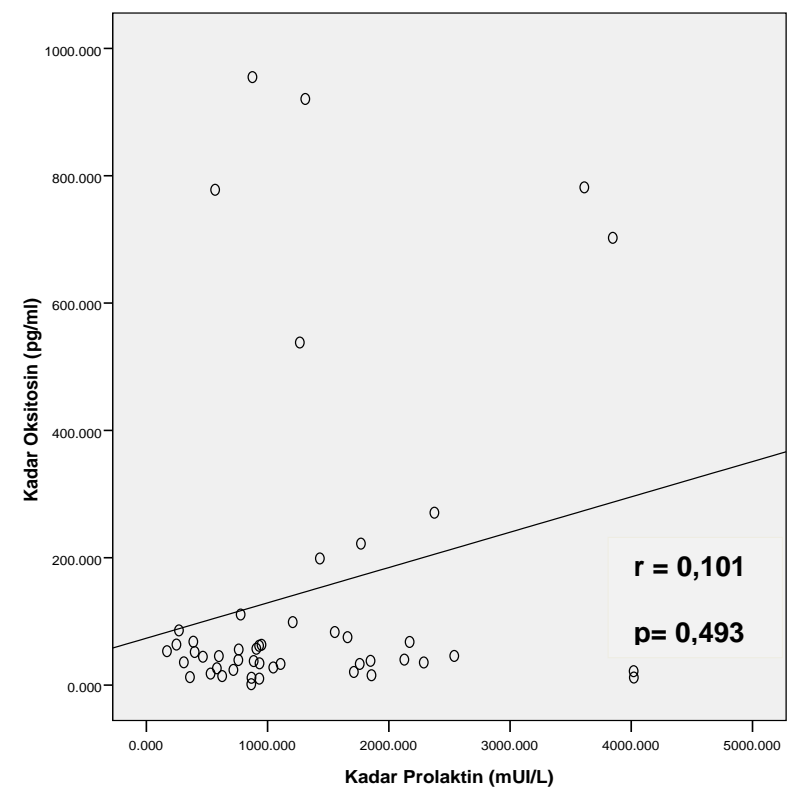

Gambar 3. Scatter Plot Korelasi Kadar Prolaktin dengan Oksitosin pada Ibu Menyusui Eksklusif

\section{Korelasi Kadar Prolaktin dengan Lama Amenore Laktasi}

Hasil uji statistik mendapatkan nilai $\mathrm{r}=0,331$ dan nilai $\mathrm{p}=0,022$. Terdapat korelasi positif yang lemah dan signifikan antara kadar prolaktin dengan lama amenore laktasi. Semakin tinggi kadar prolaktin maka semakin meningkatkan lama amenore laktasi, dengan nilai $\mathrm{r}^{2}=0,102$, dapat diartikan kadar prolaktin berkontribusi sebasar $10,2 \%$ terhadap lama amenore laktasi, sedangkan
$89,8 \%$ sisanya ditentukan oleh faktor lain yang tidak diteliti seperti asupan nutrisi, merokok, umur, pekerjaan, obesitas dan obat-obatan.

Pada ibu yang tidak menyusui eksklusif biasanya, ovulasi pertama terjadi antara 4 dan 8 minggu postpartum sehingga mengalami pemulihan yang cepat dari fungsi ovarium. Sebaliknya, ibu yang menyusui eksklusif memiliki masa amenore laktasi dan infertilitas yang dapat berlangsung dari dua bulan sampai dua tahun atau lebih. Periode infertilitas ini berhubungan dengan menyusui yang telah memberikan kontribusi signifikan terhadap jarak kelahiran. Meskipun demikian, beberapa wanita yang menyusui eksklusif akan pulih kembali fungsi ovariumnya sebelum enam bulan setelah melahirkan (García \& Mella, 2013).

Perez et al. (1992) melakukan penelitian pada 200 wanita dengan studi prospektif, dimana ibu postpartum dilakukan diagnosis ovulasi pertama kali dengan biopsi endometrium, suhu tubuh basal, evaluasi sitologi vagina, dan lendir serviks. Tanggal ovulasi pertama, menstruasi pertama dan status menyusui dianalisis. Tidak ada wanita menunjukkan tanda-tanda ovulasi sebelum hari ke36, apakah menyusui atau tidak. Intensitas menyusui dapat memengaruhi terjadinya ovulasi sebesar $78 \%$ dari wanita yang berovulasi sebelum menstruasi pertama, tetapi hanya 12 kehamilan terjadi dengan ovulasi pertama. Dari 170 ibu menyusui, terdapat 24 ibu menyusui eksklusif yang mengalami ovulasi, 49 ibu menyusui parsial, dan $97 \mathrm{ibu}$ yang melakukan penyapihan.

Berdasarkan hasil penelitian Wei (2007) melakukan studi pada 101 wanita menyusui menunjukkan bahwa dari 53 wanita $(52,5 \%)$ mengalami ovulasi pertama kali dalam 154 hari setelah persalinan dengan diameter folikel $>1,8$ $\mathrm{cm}$ dan mengalami menstruasi pada hari ke $138 \pm 84$. Terdiri dari 48 wanita dengan diameter folikel $\leq 1,7 \mathrm{~cm}$ mengalami menstruasi kembali dalam $293 \pm 88$ hari. Waktu kembalinya menstruasi juga berkorelasi dengan pemberian makanan pengganti ASI pada bayi $(\mathrm{r}=0,56, \mathrm{p}<0.01)$ dan waktu terjadinya ovulasi pertama kali setelah persalinan $(r=0,48, p<0.01)$. 
Hasil penelitian ini sesuai dengan penelitian Stallings et al. (1996) menyatakan bahwa terdapat hubungan kadar prolaktin dengan amenore pada ibu menyusui $(p<0,001)$ dan penurunan kadar prolaktin memiliki hubungan dengan bertambahnya usia bayi $(\mathrm{p}<0,05)$. Berdasarkan model akhir uji cox regresi, ibu yang tidak memberikan ASI eksklusif pada bayinya mempunyai amenore laktasi 1,3 kali lebih pendek dibandingkan ibu yang memberikan ASI eksklusif (95\% CI: 1,01-1,67).

Hasil penelitian ini tidak sesuai dengan penelitian Valldes, et al. (1991), dimana melakukan penelitian pada 45 ibu menyusui eksklusif. Hasil penelitian Valldes, et al. menyatakan tidak ada hubungan antara menstruasi pada 6 bulan postpartum dengan peningkatan kadar prolaktin setelah menyusui. Namun, hasil penelitian Valldes, et al. menyatakan bahwa kadar prolaktin dasar memiliki korelasi dengan durasi amenore laktasi pada ibu yang menyusui eksklusif. Perbedaan hasil penelitian ini dengan penelitian Valldes, et al. dikarenakan pada penelitian Valldes, et al. melakukan pengukuran kadar prolaktin dilakukan dengan mengambil sampel darah pada 3 bulan postpartum dan dilakukan 2 kali yaitu sebelum dan sesudah menyusui.

Ditemukannya korelasi yang sangat antara kadar prolaktin dengan amenore pada ibu menyusui eksklusif karena ada beberapa ibu yang mengalami amenore sebelum 4 bulan postpartum. Hal ini terjadi karena banyak faktor yang memengaruhi lama amenore laktasi seperti frekuensi pemberian ASI, pendidikan, umur dan lain-lain. Akan tetapi apabila sudah menstruasi maka terjadi peningkatan risiko untuk terjadinya kehamilan.

\section{Korelasi Kadar Oksitosin dengan Lama Amenore Laktasi}

Hasil uji statistik mendapatkan nilai $r=-0,085$ dan nilai $\mathrm{p}=0,565$. Terdapat korelasi negatif yang sangat lemah dan tidak signifikan antara kadar oksitosin dengan lama amenore laktasi, sehingga dapat disimpulkan bahwa semakin tinggi kadar oksitosin maka semakin menurunkan lama amenore laktasi. Berdasarkan hasil analisis statistik didapatkan bahwa kadar prolaktin memiliki korelasi yang lebih besar dibandingkan dengan kadar oksitosin.

Belum ada penelitian sebelumnya yang meneliti tentang kadar oksitosin dengan amenore laktasi. Oksitosin bekerja dalam sel granulosa, tetapi tidak dalam sel teka. Ovulasi atau luteinisasi spontan mulai memuncak pada fase luteal awal dan berhenti sekitar pertengahan siklus menstruasi. Konsentrasi oksitosin pada fase luteal mencapai tingkat maksimal sekitar pertengahan siklus menstruasi dan kemudian konsentrasi oksitosin menurun ke tingkat rendah pada fase luteal akhir. Oksitosin memiliki sedikit atau tidak ada efek langsung pada produksi progesteron luteal. Akan tetapi oksitosin menghambat produksi $\mathrm{LH}$ sehingga oksitosin berperan dalam proses luteolytic pada korpus luteum (Funchs, 1988).

Tidak ditemukannya korelasi kadar oksitosin dengan lama amenore laktasi dapat disebabkan karena LH dan FSH rendah yang dipengaruhi tingginya prolaktin. Rendahnya kadar oksitosin akan berkontribusi terhadap amenore laktasi dan sebaliknya semakin tinggi kadar oksitosin maka akan menyebabkan menstruasi. Jadi, lama amenore laktasi pada ibu menyusui eksklusif berhubungan dengan refleks menyusui karena dipengaruhi oleh siklus hormonal.

\section{KESIMPULAN}

Semakin tinggi kadar prolaktin maka semakin bertambah lama amenore laktasi dan semakin tinggi kadar oksitosin maka semakin berkurang lama amenore laktasi.

\section{UCAPAN TERIMA KASIH}

Penulis mengucapkan terima kasih kepada Kepala, Staf dan Kader Puskesmas Belimbing Padang, Kepala dan staf laboratorium Biomedik Fakultas Kedokteran Universitas Andalas, Bapak Direktur Utama Lembaga Pengelola Dana Pendidikan (LPDP) Kementerian Keuangan Republik Indonesia yang telah membantu penyelesaian tesis ini. 


\section{DAFTAR PUSTAKA}

American Academy of Pediatrics Section on Breastfeeding., 2005. Breastfeeding And The Use of Human Milk. American Academy of Pediatrics.

Ballard, O., \& Morrow, A. L., 2013. Human Milk Composition: Nutrients And Bioctive Factors. Pediatr Clin North Am, 60, 1-24. http://doi.org/10.1016/j.pcl.2012.10.002.Hum an.

Blackburn, S. T., 2013. Maternal, Fetal, \& Neonatal Physiology. A Clinical Perspective. $4^{\text {th }}$ Ed. Elsevier.

Dinas Kesehatan Kota Padang (DKK)., 2014. Profil Kesehatan Kota Padang Tahun 2014.

Fuchs, A. R., 1988. Oxytocin and ovarian function. J Reprod Fertil Suppl. http://www.ncbi.nlm.nih.gov/pubmed/305720 1. 36:39-47.

Garcia, P. V., \& Mella, C., 2013. Analysis of Factors Involved in Lactational Amenorrhea. Journal of Biosafety \& Health Education, 01(04), 1-5. http://doi.org/10.4172/2332$\underline{0893.1000109 .}$.

Gimpl, G., \& Fahrenholz, F., 2010. The Oxytocin Receptor System : Structure, Function, And Regulation, 81(2), 629-683.

Guyton, A. C., \& Hall, J. E., 2006. Textbook of Medical Physiology. $11^{\text {th }}$ Ed. Philadelphia, PA, USA: Elsevier Saunders.

Heymann, J., \& Earle, A., 2013. Breastfeeding policy: a globally comparative analysis, (April), 398-406.

Jamillah., Suwondo, A., Suhartono., \& Wahyuni, S., 2014. Efektifitas Kombinasi Pijat Oksitosin teknik Effleurage dan Aromaterapi Rose terhadap Kadar Prolaktin Ibu Postpartum Normal Di Wilayah Puskesmas Dawe Kudus Tahun 2013, 5(1), 97-110.

Kementerian Kesehatan Republik Indonesia (Kemenkes RI)., 2013. Pekan ASI Sedunia 2013. Breastfeeding Support. Akses 11 Oktober 2015. http://www.gizikita.depkes.go.id/pekan-asisedunia-2013/.
Lawrence, R. M., \& Lawrence R. A., 2014. Creasy And Resnik's Maternal-Fetal Medicine principles And Practice. $7^{\text {th }}$ Ed. Elsevier Inc.

Lennartsson, A.-K., \& Jonsdottir, I. H., 2011. Prolactin in response to acute psychosocial stress in healthy men And women. Psychoneuroendocrinology, 36(10), 1530-9. http://doi.org/10.1016/j.psyneuen.2011..007.

Liu, Y., Gold, B. E., Lasley, L. B., \& Johnson, O. W., 2004. Factor Affecting menstrual Cycle Characteristics.

http://aje.oxfordjournals.org/content/160/2/13 1.full.pdf+html.

Lonstein, J. S., 2007. Regulation of anxiety during the postpartum period. Frontiers in Neuroendocrinology, 28(2-3), 115-141. http://doi.org/10.1016/j.yfrne.2007.05.002.

Perez, A., labbok, M. H., \& Queenan, J. T., 1992. Clinical Study of the Lactational Amenorrhea Method for Family Planning. Lancet.

Riset Kesehatan Dasar (Riskesdas)., 2013. Badan Penelitian dan Pengembangan Kesehatan Kementerian Kesehatan RI Tahun 2013.

Stallings, J. F., Worthman, C. M., Panter-Brick, C., Coates R. J., 1996. Prolactin Response to Suckling and Maintenance of Postpartum Amenorrhea Among Intensively Breatfeeding Nepali Women. Departement of Anthropology, Emory University Ahanta, GA (JFS,CMW).

Survei Demogrofi Kesehatan Indonesia (SDKI)., 2007. Survey Demografi Kesehatan Indonesia. BKKBN., BPS., Depkes R.I., Macro, I \& Calverton, M, USA. Akses 11 Januari 2015. http://www.depkes.go.id/resources/download. pdf.

Survei Demografi Kesehatan Indonesia (SDKI)., 2012. Survey Demografi Kesehatan Indonesia. Akses 11 Januari 2015. BKKBN., BPS., Kemenkes, R.I., Measure DHS \& ICF, I.

http://www.depkes.go.id/resources/download. pdf.

Veldes P, Sierralta P, Barria A, Fiqueroa C, Bery V, Aravena M, Ossa X, Cardenas H, 1991. 
Influence of Basal and Post-feeding Prolactin Levels on Amenorrhea During Breastfeeding. Rev Chil Obstetrics Ginecology.

Wei L., Yi Q., 2007. Relation of supplementary feeding to resumptions of menstruation And ovulation in lactating postpartum women. Chin Med J; 120(10):868-870.

World Health Organization (WHO) \& The United Nations Children's Fund (UNICEF)., 2012. Breasfeeding Conselling A Training Course. Participans Manual Part One. Session 1-9.

World Health Organization (WHO)., 2002. Infant and child nutrition: global strategy on infant And young child feeding. Akses 11 Oktober 2015. Available at: http://apps.who.int/gb/archive/pdf files/WHA55/e a5515.pdf. 